\title{
Experience in the adoption of Room \& pillar mining method in the company OKD a.s., Czech Republic
}

\author{
Vlastimil Hudeček ${ }^{1}$, Jindřich Šancer ${ }^{1}$, Václav Zubíček ${ }^{1}$ and Jiří Golasowski ${ }^{2}$
}

\begin{abstract}
A significant quantity of available hard coal reserves in the area of Upper Silesian Basin in the Czech Republic occurs below the areas where surface mine subsidence is unacceptable or may be only minimal. An effort is made to mine these reserves by means of a new, mining method yet not approved for the joint-stock company OKD, a.s., namely a special modification of the continuous mining method Room \& Pillar. The main objective is to eliminate the mentioned surface restraints by leaving stable pillars of coal to support the overlying strata.

For this reason, CSM Sever, Mining Plant 2 of OKD, a.s. realised a test run to verify the problems arising during mining at high depths, when implemented in an area where it has never been used before.

The article is based on published in Journal of Mining Science in the year 2015. In the article, the authors are concerned with the description of stress-strain monitoring of pillars left after test operation, including its continuous evaluation and evaluation of important operating conditions and activities.

The objective of monitoring is to gather sufficient information to assess whether the Room and Pillar extraction method can be used in areas where there is a risk of rockburst.
\end{abstract}

Keywords: room and pillar, mining method, OKD, stress-strain monitoring

\section{Introduction}

The only mining method used in the Ostrava-Karviná Coalfield for a long time is longwall mining along the strike with caving. By long-term mining operations in this region, a considerable quantity of coal has been exploited; however, still, the sufficient potential consisting of coal reserves suitable for mining exists here. Nevertheless, a comparatively significant quantity of these available coal reserves occurs in densely populated areas, where surface subsidence is unacceptable.

New possibilities and forms of coexistence with towns and municipalities are sought, when many new acts and valid regulations determining the authorisation of mining activities and especially the solution of so-called conflicts of interests, i.e. protection of property of physical and legal entities must be respected.

The basic factor limiting the mining activities is the level of influence on surface structures affected by expected mining activities (magnitude of subsidence or undermining) (Vochta, 2016). Classical development performed beyond the existing boundaries as a result of the extension of the mining claim, when common mining procedures are used, is, with regard to comparatively demanding legislation regulating the authorisation of mining operations in such densely populated area, difficult to put into practice or almost impossible. The finding of a suitable alternative method of mining, which would solve the conflict of producer's interests and property owners' interests on the surface, is thus one of few opportunities of extending the life of coal mines.

The method of continuous mining Room \& Pillar, enabling certain special modification usable in conditions of hard coal underground mines of the coal basin of this place and accepting great tectonic ruggedness, dips of layers of up to 20 degrees and mining depth of 750 to $900 \mathrm{~m}$ below surface, was selected. The main objective was to eliminate the mentioned significant restraints on the surface by leaving stable coal pillars to support the overlying layers; the pillars should prevent bed separation in the overlying strata and provide the necessary protection of surface structures (Zhang, 2017).

After considering several localities, a protective pillar of shafts of the locality ČSM-Sever, mine plant 2 as the place for test operation of a new mining method not approved yet was selected. The basic characteristics of a mining plan for the area were published in (Mikoláš, 2012; Hummel et al., 2015; Golasowski, 2016).

\section{Laboratory research}

In the laboratory research, the main attention was paid to determining the mechanical properties of coal from the concerned locality. The research was mainly focused on the specification of the bearing capacity of pillars when using the method of room-and-pillar mining. For this purpose, mainly compressive strength with a different slenderness ratio has been investigated - from the normalised slenderness ratio 1 to the slenderness ratio which approximates the slenderness ratio of pillars in mining conditions. In these conditions, the measured compressive strength was up to $112 \mathrm{MPa}$. The plurality of measured values was used to compile the regression

\footnotetext{
${ }^{1}$ Vlastimil Hudeček, Jindřich Šancer, Václav Zubíček, Institute of Mining Engineering and Safety, Faculty of Mining and Geology, VŠB Technical University of Ostrava, 17. listopadu 15, 70833 Ostrava - Poruba, Czech Republic, vlastimil.hudecek@vsb.cz, jindrich.sancer@vsb.cz, vaclav.zubicek@vsb.cz

2 Jiři Golasowski, OKD a.s., Karviná, Czech Republic, jiri.golasowski@ okd.cz
} 
equation for compressive strength according to the slenderness ratio, see Figure 1, which can serve for the evaluation of the bearing capacity of pillars, and thus evaluation of their safety.

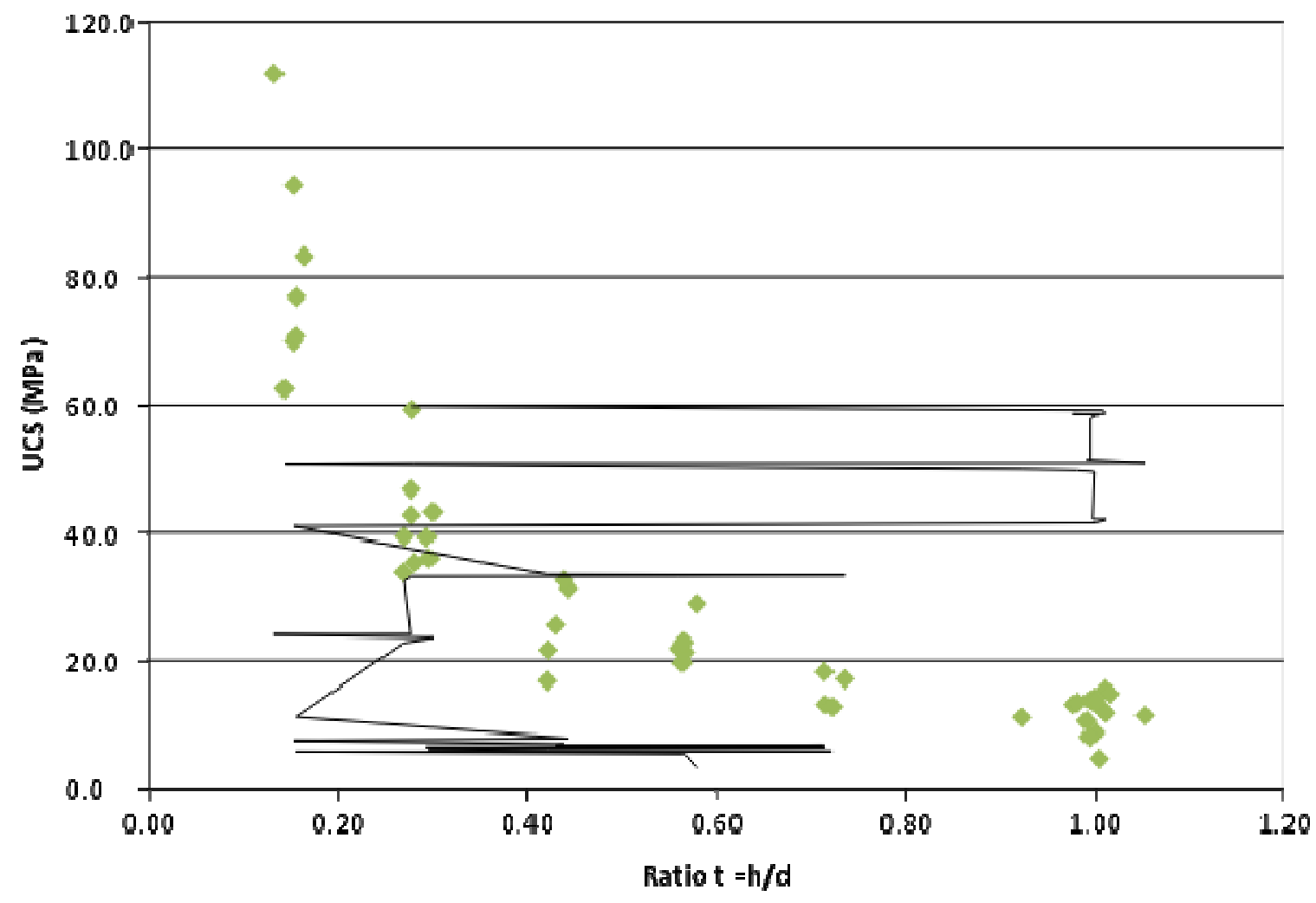

Fig. 1. Dependence of simple compression strength (UCS) of coal on the slenderness ratio.

The mechanical properties of coal were also the basis for determining the modulus of deformation, Poisson number and angle of internal friction. Evaluation of these properties is of great importance for modelling subsidence of overlying rocks and thus of the surface. Like in the case of UCS, the modulus of deformation value is significantly dependent on the slenderness ratio (Jin et al., 2016).

\section{Monitoring}

The decision of the mining authority (OBÚ v Ostravě, 2013) imposes a duty on the organisation to observe, in the framework of test operation, the course of test operation and to evaluate results after the operation. Increased attention should be paid to chosen parameters especially in the following areas:

- mining and technical - especially stability and life of operated mine roads, their maintenance requirements, load-bearing capacity of support and its efficiency,

- operating and safety - dealing with occupational and operational safety especially in the areas of ventilation, spontaneous fire prevention, coal dust disposal,

- the operation of machines and equipment means the verification of all measures that were determined in the framework of the certification process for specific machines and pieces of equipment, their reliability and efficiency in the conditions of the company OKD, a.s.. Moreover, the long-term functionality and operating reliability of installed technology mainly in cases when mechanisms will operate at technical limits defined by manufacturers must be verified,

- observation and measurement on the surface should prove the real influence of this mining method on the surface (Vochta, 2016, Waclawik, 2017),

- the economics of operation should prove the economic viability and profitability of the method even at a very low level of recovery.

For meeting the requirement for monitoring in the mine, which followed from recommendations formulated in the expert evaluation of the project on the yet not approved new mining method (Korbel, 2014) and was later included into the decision of District Mining Authority (OBÚ v Ostravě, 2013), a project on geotechnical and geomechanical monitoring and its modification in excavation V (Waclawik et al., 2013; Waclawik et al., 2014) was prepared. 
The geotechnical or stress-strain monitoring deals with the detailed observation of stability of coal pillars, stability and life of long mine workings, suitability of used supports, and is necessary for subsequent assessment whether the methodology of calculation using the program ARMPS can be used for the dimensioning of stable pillars left between mine roads in conditions of the Czech part of the Upper Silesian Coal Basin (Schloemer et al., 2014; Schloemer et al., 2016, Schreiber et al., 2017). The objective of geotechnical monitoring is to gather sufficient information for the assessment whether the mining method Room \& Pillar can also be used in the areas where a rock burst hazard exists. In addition to the collection of needed data and long-term observation, monitoring should also provide prospective indication and identification of potential geotechnical and geomechanical hazards in the course of test operation. The potential geotechnical and geomechanical hazards are based on both an adopted algorithm for the calculation of pillar stability and general risks considered in the area of road stability and rock burst problems. As the potential geotechnical and geomechanical hazards, the following items can be regarded according to (OBÚ v Ostravě, 2013):

Failure of left coal pillars:

- increasing the load on coal pillars without manifestations of brittle deformation,

- brittle failure of the coal pillar, such as crushing and sliding of crushed marginal parts of the pillar into roads.

Failure of overlying rocks above left coal pillars:

- $\quad$ stress changes without manifestations of brittle deformation,

- brittle failure of overlying rocks above left pillars and bed separation in the rocks.

Failure of overlying rocks above driven roads:

- plastic deformation,

- brittle deformation and bed separation in the rocks.

The hazards mentioned above were incorporated into the proposed monitoring method, including the recommended means. As a consequence, values of warning conditions were determined and recommended; if they are reached, additional measures are necessary.

The layout of individual devices of geotechnical monitoring can be seen in Figure 2.

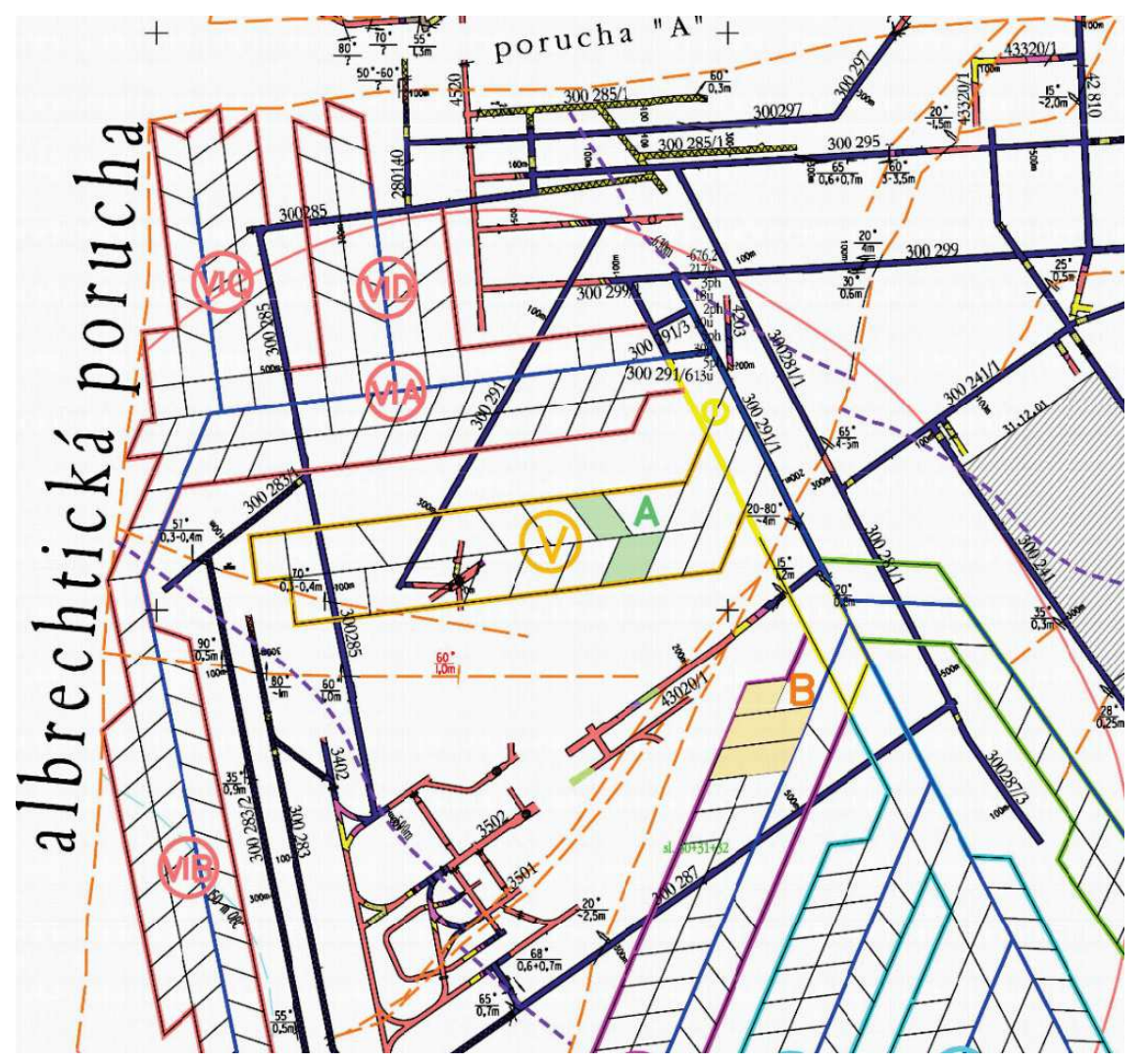

Fig. 2. Location of monitored pillars in locality A of excavation V and locality B of excavation II (Waclawik et al., 2013). 


\section{Project on stress-strain monitoring}

For the implementation of stress-strain monitoring, two pillars at the beginning of the excavation V (locality A) and two pillars in the excavation II (locality B) were selected so that observation could be performed on a long-term basis even after completion and closure of the excavation, see Fig. 2.

Monitoring implementation according to (Waclawik et al., 2014) by means of the installed devices includes:

Measurement of deformation of overlying rocks above roads; for this purpose, three monitoring elements, namely extensometers, tensometric bolts and probes CCBM were installed.

Observation and measurement of stress state in the rock mass in in-situ conditions carried out by installed probes CCBO or CCBM with the possibility of determining the total tensor of state of stress (stress field) of the rock mass and perhaps of observing its changes.

Observation of changes in coal pillar loading; in the left coal pillars, stress cells measuring the uniaxial vertical load are installed.

Measurement of coal pillar deformation; at half the side of the monitored left pillars, extensometers are installed sub-horizontally in the coal substance.

Observation of the load on installed anchor elements, which is ensured by hydraulic dynamometers mounted on strand anchors.

Measurement of road convergence by means of stabilised convergence sections (Kajzar et al., 2016)

Location of the devices of geotechnical monitoring can be seen in Figure 2.

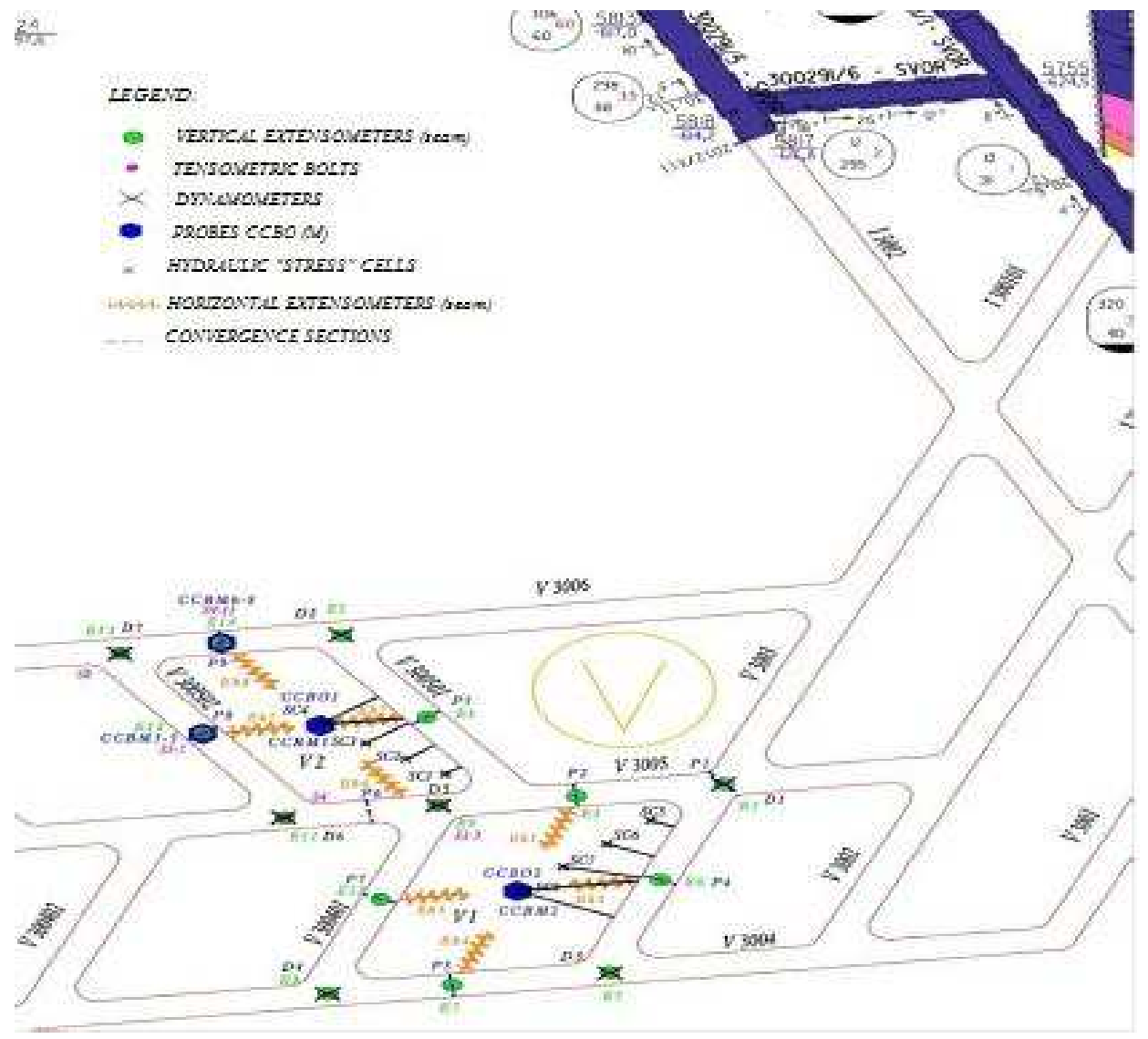

Fig. 3. Location of monitored pillars in locality A of excavation V(Waclawik et al., 2014).

\section{Continuous evaluation of monitoring}

Information about the course of monitoring is processed in partial reports submitted to the District Mining Authority in Ostrava. Assessment is ensured by working groups of specialists participating in the implementation of monitoring with members of the project team. The final objective of monitoring is to provide in principle two different information sources: 
Instantaneous, associated with occupational and operational safety, coordination and specification of next steps in relation both to the current state of mining operations in the excavation and to the capture of information in the case of possible signalling hazardous conditions.

Long-term, which will confirm the correctness of set parameters of calculation of dimensions of coal pillars as well as an assumption of their behaviour in the given conditions so that the used procedures, especially according to the program ARMPS, could be used in routine operation; further, it will help to collect enough information for assessing whether the mining method Room \& Pillar can also be used in areas where the hazard of rock burst occurrence exists.

The implemented monitoring of the state of stress of monitored pillars characterises their failure and defines deformation zones in the pillars (Golasowski et al., 2014). From the development of monitored vertical stress, we can conclude that the undamaged core of the pillar gradually decreases due to the advance of mining. Based on the assessment of dynamics of loosening the pillar of coal observed by horizontal extensometers we can state that in the framework of the whole test operation the loosening of the left pillar slows markedly down. From the decreasing dynamics of movements on installed horizontal extensometers, convergence measurements and 3D laser scanning, we can expect at the present level of knowledge that pillar deformation and pillar load-bearing capacity can be stabilised. Nevertheless, one cannot predict whether and when the loosening of the pillar will be finished, and the pillar will be stabilised.

However, yet it can be stated that the taken measurements have confirmed the correctness of formulated theoretical assumptions of the behaviour of the rock mass and coal pillars of specified dimensions. During the test operation, any anomalous conditions endangering the occupational and operational safety, which would indicate errors in projects and/or calculations, have not been recorded yet. It is especially data concerning the application of program ARMPS for coal pillar design that should confirm mainly the applicability of algorithms, with which the program works. From the point of view of the operation, it is necessary to state that the observations have confirmed pillar deformation, mapped its dynamics, intensity and time course; the effects of mining are much longer than the time necessary for the mining of reserves from the excavation $\mathrm{V}$, i.e. mining operations took place much faster than dynamics of deformation of coal pillars. However, it is beyond doubt that the mentioned partial conclusions and previous experience have to be confirmed again by repeated measurements and observation from the long-term prospects. To this step, the second stage of monitoring stated in the monitoring project, which will be focused on the locality B of excavation II, leads, see Fig. 2.

\section{Assessment of important operating conditions of test operation}

Stability of mine workings

a) Bolt support

Based on the acquired information from the previous operation, performed inspections, observation of extensometers and convergence measurements, bolting patterns were modified to increase efficiency, effectiveness and safety when mining with the use of the yet not approved new mining method. Roof bolting patterns were changed in comparison with the original basic project; for usual conditions, from original 4 pcs to 6 pcs per metre, for worsened conditions 6 pcs per metre, and for poor conditions, 6 pcs + 2 pcs per metre remained without a change in the original project. Increased attention was paid to the bolting of walls, especially adherence to both technology and quality of bolting. The bolting pattern was changed from one type, 2 pcs per metre +2 pcs per metre after backing a drilling machine by means of Alminco Bolter for all conditions to three types according to the geological conditions. For usual conditions, 3 pcs per metre supplemented by 1 pc per metre in the lower part of the mine working after backing the drilling machine for the reason of damaging the mine working. For worsened conditions, 3 pcs $+1 \mathrm{pc}$ per metre after backing the drilling machine out, and for poor conditions, $6 \mathrm{pcs}+1 \mathrm{pc}$ per metre after backing. Fibreglass bolts were replaced by steel ones 2.4 and $2.8 \mathrm{~m}$ long. The mentioned updating was incorporated in a supplement to the project on bolt support when mining with the use of the new mining method not yet approved and confirmed in accordance with legislation by the expert organisation, Green Gas DPB, a. s. Observations confirm that during the operation, the walls are pushed out. Nevertheless, the results of geotechnical monitoring confirm that manifestations correspond to time changes in the coal pillar and possible increased degree of pushing out is caused neither by technical shortcomings nor by technological indiscipline. To bolting the walls, increased attention will be paid in future as well.

b) Floor swelling and changes in shape of mine roads

In the course of mining with the application of the not yet approved new mining method, floor swelling and changes in mine road shape occur in mined-out workings. Mine workings with increased convergence have to be restored, floor dinting is carried out, bolts in walls are thickened, supports of walls are repaired, and repeated bolting is performed. 
By regular inspection of mine workings, it has been proved that manifestations of convergence of the walls and the floor do not affect the stability of the roof (overlying strata), and the workings can be operated safely when operated under the measures mentioned above. The mentioned condition is still monitored. The condition of mine workings and the manifestations of floor swelling are illustrated in documentary photographs in Figures 4 and 5.

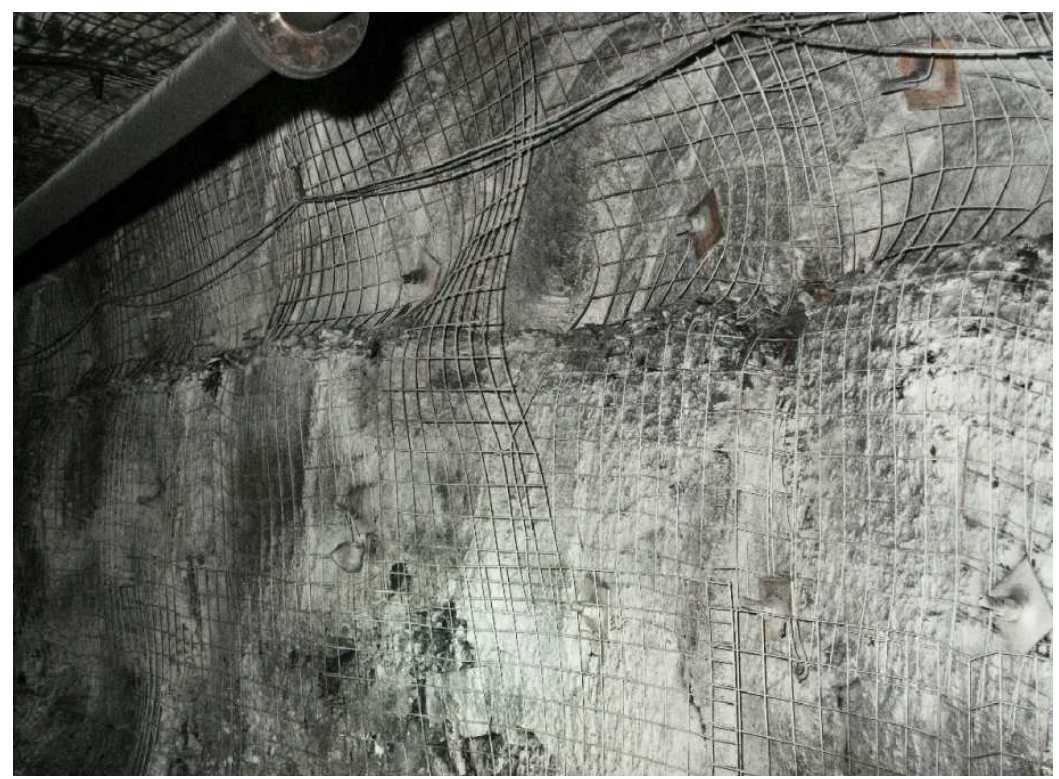

Fig. 4. Documentation on bolting road walls.

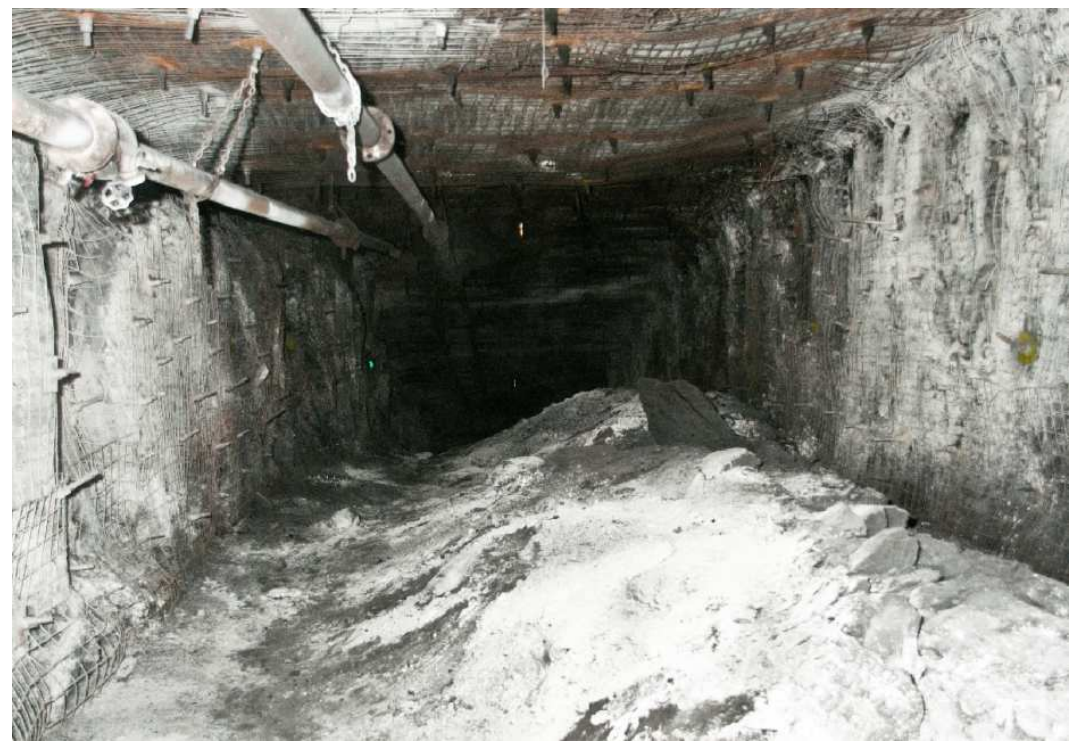

Fig. 5. Photo-documentation on floor swelling in the working

c) Results of checks on extensometers

As of 31st October 2015, altogether 217 two- and three-stage mechanical extensometers were installed and checked in excavation V and mining base I as well as in mine workings 300285 and 300291 associated with mining operations with the use of the new mining method not approved yet. After closing a part of excavation V and mine workings 300291 and 300 285, 93 mechanical extensometers are checked in the area as of 31st October 2015. When checking the extensometers during the test operation, exceeding the critical value of bed separation in the overlying strata above the mine working 300 291/1, stationing 296 $315 \mathrm{~m}$, in the part of the mine working driven in the place of tectonic fault - thrust fault in the period from September to October 2012 (extensometers Nos. 20, 16 and 21) and the place of intersection of roads V 3004 and V 300404 was found. Without delay, measures to ensure safety were determined and implemented. In addition to the parts mentioned above, any exceeding the critical value of bed separation in the overlying strata was not found on the extensometers. 
d) Passing of road I 3002 through the thrust fault

When preparing a work schedule in the area of application of the new mining method not yet approved, the verification of possibilities of passing through the tectonic zone of thrust fault character with the use of installed technology was expected in the case of the extension of the mining base I. The thrust fault with a throw of about $1.3 \mathrm{~m}$ was reached by the road I 3002 at stationing (henceforth referred to as st.) $174 \mathrm{~m}$ on the 11th October 2015. Based on the interpretation of the development of the thrust fault, a way of passing through the thrust fault plane was proposed, see Figure 6.

At the same time, the following necessary measures were proposed:

- In the part of the road I 3002 from st. 160 to st. $179 \mathrm{~m}$, the roof was supported according to the pattern "poor conditions", 2 rod bolts $2.8 \mathrm{~m}$ long were applied, from st. $160 \mathrm{~m}$ to st. $163 \mathrm{~m}$ and from st. $164 \mathrm{~m}$ to st. $179 \mathrm{~m}, 3$ cord bolts $6 \mathrm{~m}$ long per metre of advance were applied.

- Furthermore, at st. $172 \mathrm{~m}$ to st. $179 \mathrm{~m}, 9$ cord injecting bolts IR/IN $8 \mathrm{~m}$ long were installed and injected with resin products Bevedol and Bevedan. The roof at st. $172 \mathrm{~m}$ to st. $179 \mathrm{~m}$ is also supported by means of 11 supports TH anchored in the roof by 16 rope bolts MCA-M that are 13 and $15 \mathrm{~m}$ long. The end of the road is supported in advance by 20 injecting bars (IBO) R 32 of the length of $6 \mathrm{~m}$ and through them injected with Bevedol, Bevedan. The walls of the working at st. $160 \mathrm{~m}$ to st. $179 \mathrm{~m}$ were supported and injected with Bevedol, Bevedan by IBO rods R32 and R25 of the length of $6 \mathrm{~m}$.

- After supporting the road as far as st. $179 \mathrm{~m}$, the Bolter Miner (BM) was backed out to st. $150 \mathrm{~m}$ and subsequently, the floor was ripped to the level of the seam behind the thrust fault (height in the section of up to $5.9 \mathrm{~m}$ ), from st. $179.5 \mathrm{~m}$ the road continues at the height of $3.5 \mathrm{~m}$.

- In the part of the road I 3002 from st. $179 \mathrm{~m}$, the roof was supported according to the pattern "poor conditions", i.e. rod bolts $2.8 \mathrm{~m}$ long (minimally 6 pcs per metre of advance) and 3 strand bolts, $6 \mathrm{~m}$ long, per metre of advance. In the stated part, the roof is damaged. For the given reason, the supporting of the roof of the working by means of supports $\mathrm{TH}$ anchored in the overlying layers by $13 \mathrm{~m}$ long rope bolts was initiated.

- Check on individual bolts has not proved any deformation of bolt washers.

The final situation after passing of road I3002 through the thrust fault is shown in Fig. 6.

\section{Operation of machines and equipment in the area of application of the new mining method not approved yet}

a) Operation of machines and equipment

During the test operation, any serious defect leading to a dangerous situation has not occurred yet. During the operation, short circuits, overheating or another serious or dangerous condition of machines have not occurred. Machines are operated under arduous conditions given by the selected area of application of the new mining method not approved yet (soft floor, dips, brushing of associated rocks). After completion of crew training and putting all machines in the area into operation, it can be stated that the operation of machines takes place in accordance with technical documentation for the given machines, and as the results of operation show, the crew is able to manage safe operation under these conditions.

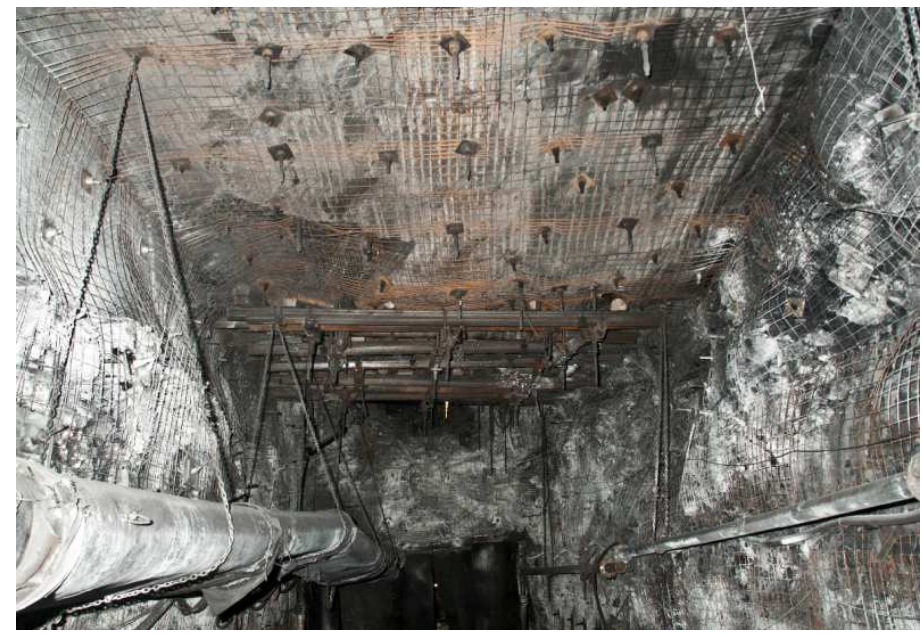

Fig. 6. Photo-documentation on passing of road 13002 through the thrust fault-roof support. 
b) Brushing of associated rocks

Brushing of associated rocks (overlying as well as underlying rocks) does not cause any problems in mining.

c) Soft floor

During the test operation, the operation of machines in the area of application of the new mining method not approved yet has been gradually improved above all thanks to crew training, improvement of working practices, improvement of maintenance of mine workings (floor dinting and cleaning by means of Scoop and also manually), and in necessary cases by laying an artificial floor or sleepers with binding by means of anchored supports $\mathrm{TH}$.

In parts with long-term operation of wheeled vehicles (above all 430 20/1 in the point of crossing the seam), laying the artificial floor made of sleepers $4 \mathrm{~m}$ long was tested successfully. The mentioned way of reinforcement seems to be best for increasing the life of the floor; higher costs are compensated by saving in material and decrease in shifts necessary for frequent repairs of reinforcement with another material. It is also continuous watering and salting the floor with magnesium chloride, which causes its compaction and makes the disposal of dust on the floor more efficient, that influence positively the operation of wheeled vehicles.

d) Turning of the drilling machine Bolter Miner

During the test operation, the turning of the drilling machine to development roadways at an angle of $90^{\circ}$ from V 3007 to V 300505 , from V 3005 to V 300405 and from V 3004 to V 300406 was tested. In contrast to usual turning at an angle of $60^{\circ}$, this manner is technologically much more difficult; in combination with a soft floor and especially with increased traverse and longitudinal dips of the seam (more than $10^{\circ}$ ) it brings a decrease in advance rates, additional work and increased demands for the abilities of a crew of the drilling machine. After considering all experience, it was determined that the turning of the drilling machine at an angle of $90^{\circ}$ would be carried out only in exceptional cases when required by specific mine situations.

Ventilation

During the test operation, two situations important from the point of view of ventilation were recorded:

a) If oval air ducts are repeatedly used, internal seals of air duct joints, which are part of them, lose functionality. External sealing of joints of air ducts ensuring meeting the required ventilation parameters was ordered and is carried out. The mentioned situation is being solved with the company CFT supplying oval air ducts; the company is preparing replaceable internal seals - the situation will continue to be monitored.

b) For meeting the required parameters of suction mine ventilation, regular cleaning of filters in wet dust separators and channel of the movable end of the air duct is necessary. The mentioned works are included in the program of works in the shift for maintenance and preparatory work; the parameters of the air duct are regularly checked at measuring the volume rate of mine airflow in the area of application of the new mining method not approved yet.

Disposal of coal dust, prevention of spontaneous combustion in its early stage

In places determined by the technological process for mining with the use of the new mining method not yet approved, samples for checking the spread of dust are taken monthly. For the disposal of coal dust on the floor, especially in places of operation of wheeled vehicles, application of magnesium chloride (salting), which together with floor watering also improves conditions for the operation of these vehicles, has proved to be effective. After advancing mining operations, inert dust is regularly spread along the circumference of the mine working on the base moistened by spraying a substance suppressing oxidation and spontaneous combustion of coal (10 percent $\mathrm{CaCl} 2$ solution).

\section{Conclusion}

The continuous method of mining Room \& Pillar or its modification was not used in the Ostrava-Karviná Coalfield before the test operation. The objective of the test operation is to verify the possibility of implementing the modification of mining technology Room \& Pillar in local conditions of the selected mine and, based on the obtained results, to achieve the approval of the State Mining Authority for introducing the new mining method Room \& Pillar into common operations in the mines of the company OKD a.s.. With regard to comparable conditions in the mines of OKD a.s., the possibility of spreading the method generally in the environment of underground hard coal mines of the Upper Silesian Basin can be considered. 
The preparation, as well as implementation of the test operation, has provided a lot of important information and experience. In the article, we focus primarily on the practical areas of the problem to facilitate the introduction and later also the use of the new mining method as much as possible.

So far, the experience has confirmed the satisfactory sizing of pillars from the point of view of the operation in the mine, i.e. occupational safety and operating reliability. Another requirement for pillar stability is associated with the main objective of the method, namely minimisation of surface effects of mining. For confirming this portion of parameters of the new method, the completion of long-term surface observations will be necessary. In the framework of the approval process, this part of the problem can also be solved; the method Room \& Pillar would be regarded as a method not inducing effects on surface infrastructure; nevertheless, the intensity of the effects would be determined in an expert mining technological opinion on surface effects of mining.

As far as proper practical operation is concerned, the existing experience in the area of occupational and operational safety shows that the application of used equipment in ventilation, disposal of coal dust, explosion prevention and prevention of spontaneous combustion in its early stage, is suitable. After necessary modifications of legislation, mining operations can thus be performed safely in future even in difficult conditions of gassy mines in the Ostrava-Karviná Coalfield.

The machines and equipment used in the technology assembly have proved to be suitable for difficult depositional conditions, and if the crew is adequately trained and technological discipline is maintained, required performance parameters, which are a prerequisite for the profitability of the mining method, can be achieved. The test operation also shows the certain potential that exists and will still exist in the optimisation of the organisation of work and operation depending upon specific conditions in which the method will be applied.

Although the test operation has not answered all questions yet, based on the existing information, we are sure that the method Room \& Pillar as a modern and flexible method has a future. If it is possible to prove that effects in the form of subsidence can be eliminated or minimized, a considerable quantity of coal reserves below densely populated areas, where the use of classical technology of longwall working along the strike with controlled caving is owing to the surface effects out of the question, can be mined in future.

\section{References:}

Golasowski, J., Vochta, R., Hudeček, V., Mikoláš, M., Dvořák, P.: Room and Pillar Mining at OKD, a.s. in the Czech Republic. 14th International multidisciplinary scientific geoconference \& expo SGEM 2014, Albena, Bulgaria, p. 529-536, ISSN 1314-2704, DOI 10.5593/sgem2014B13

Golasowski, J.: Nová dobývací metoda chodba - pilî́r v uhelných dolech. Disertační práce, Ostrava, 2016.

Hummel, M., Hummelová, I., Koudelková, J.,Černá, K.: Mining of protection pillars without subsidence. Journal of Mining Science, 51/2/, 2015, pages 335-341.

Jin, Z., Zhang, J., Li, Y.:Effect of coal room-pillar deformation on the overlying strata instability: A case study during coal panel extraction (2016) Electronic Journal of Geotechnical Engineering, 21 (13), pp. 47274737.

Kajzar, V., Kukutsch, R., Waclawik, P., Konicek, P.: Coal pillar deformation monitoring using terrestrial laser scanner technology in room and pillar panel - A case study from the Ostrava-Karvina coal field (2016) Rock Mechanics and Rock Engineering: From the Past to the Future, 2, pp. 951-956.

Korbel, J. Technologický postup nové neschválené dobývací metody CHODBA - PILÍř. OKD, a.s., Stonava, 2014.

Mikoláš, M.: Dropless mining in shafts protective pillars in the mine CSM. Diplomová práce, Ostrava, 2012.

OBÚ v Ostravě. Rozhodnutí spis. zn. SBS/43132/2012/0BÚ-05/6/511/lng.Ma, ze dne 6. 2. 2013. Zkušební provoz nové neodsouhlasené dobývací metody chodba - pilî́r v oblasti 30. sloje 2. a kry na lokalitě Sever. Ostrava, 2013.

Schloemer, W., Golasowski, J., Korbel,J.: Koncepcja i uwarunkowania geologiczne zastosowania systemu komorowo - filarowego z samodzielna obudowa kotwowa w kopalni CSM. 25 Szkola eksploatacji podziemnej. Krakow, 2016

Schloemer, W., Golasowski, J., Vochta, R., Mikoláš, M., Hudeček, V.: Challenges of Room and Pillar Mining at 900 - Meter Depths in the Czech Republic. 33 rd International Conference on Ground Control in Mining, Morgantown, WV, the USA, 2014, p. $80-86$.

Schreiber, J., Konicek, P., Stonis, M.: Seismological Activity during Room and Pillar Hard Coal Extraction at Great Depth (2017) Procedia Engineering, 191, pp. 67-73.

Vochta, R.: Výzkum vlivu dobývání metody chodba - pilî́r na povrch Dolu ČSM. Disertační práce, Ostrava, 2016.

Waclawik P. et al. Modifikace projektu monitoringu napět'o-deformačního stavu horninového masívu při dobývání sloje 30 (634) a návrh ověření možnosti použití metod protiotřesové prognózy a prevence při 
použití dobývací metody chodba-piliřr v rámci zkušebního provozu dobývací metody chodba-piliř ve sloji 30 (634) v OPJ Dolu ČSM - Sever. Projekt Ostrava: ÚGN AV ČR v.v.i. a Green Gas DPB, a.s., 2014.

Waclawik P. et al. Projekt monitoringu napětodeformačního stavu horninového masívu při dobývání sloje 30 (634) a návrh ověření možnosti použití metod protiotřesové prognózy a prevence při použití dobývací metody chodba-pilî́ v rámci zkušebního provozu dobývací metody chodba-piliřr ve sloji 30 (634) v OPJ Dolu ĆSM - Sever. Projekt (2013). Ostrava: ÚGN AV ČR v.v.i. a Green Gas DPB, a.s., 2013.

Waclawik, P., Snuparek, R., Kukutsch, R.: Rock Bolting at the Room and Pillar Method at Great Depths (2017) Procedia Engineering, 191, pp. 575-582.

Zhang, J.-X., Huang, P., Zhang, Q., Li, M., Chen, Z.:W.Stability and control of room mining coal pillars-taking room mining coal pillars of solid backfill recovery as an example (2017) Journal of Central South University, 24 (5), pp. 1121-1132.

Zhang, P., Peterson, S., Neilans, D., Wade, S., McGrady, R., Pugh, J.: Geotechnical risk management to prevent coal outburst in room-and-pillar mining (2016) International Journal of Mining Science and Technology, 26 (1), pp. 9-18. 